\title{
A STRATEGY TOWARDS DIVERSIFICATION OF OPERATIONS. THE CASE STUDY OF THE STEVEDORING ENTERPRISE
}

\author{
MARTA MAŃKOWSKA, ${ }^{1}$ MICHAŁ PLUCIŃSKI ${ }^{2}$ \\ University of Szczecin, Faculty of Management and Economics of Services, POLAND \\ 1 e-mail: marta.mankowska@wzieu.pl \\ 2 e-mail: michal.plucinski@wzieu.pl
}

RECEIVED
ACCEPTED
JEL
CLASSIFICATION

KEYWORDS

ABSTRACT
10 December 2018

28 December 2018

R40

seaports, stevedoring companies, development strategy

The main goal of the article is identification, analysis and assessment of justifiability as well as the efficiency of employing the strategy towards diversification in the operations performed by the storage and reloading companies in the Polish seaports (stevedoring enterprise). Therefore, a single case study method of the company Bulk Cargo-Port Szczecin, which is the biggest stevedoring company of the port of Szczecin, was used. In the past the company was primarily connected with handling bituminous coal exported from Poland, but nowadays it handles numerous cargoes in various reloading relations as well as provides commercial, distributional and logistic services. The objectives, which were recognised as the most important for the development of Bulk Cargo-Port Szczecin, are as follows: adaptation of the existing resources for the new, maximum depth of 12.5 $m$ in the port of Szczecin, adaptation of the handling and storage services for the complex structure based on the type, direction and subject of maritime trade cargo, extension of the storage services and establishment of flexible services with regard to the different transport modes in servicing the port of Szczecin hinterland. The accomplishment of these objectives requires appropriate (in terms of time and subject-matter) investment actions to be conducted by Bulk Cargo-Port Szczecin, which are related to the development of the suprastructure, as well as actions of the Polish maritime management and the entity managing the Szczecin-Świnoujście port complex. Thanks to its strategy for diversifying cargo, directions and functions the stevedoring company has reached its established position in the market of port services in the South Baltic.

\section{Introduction and literature review}

The turbulent environment in which modern port enterprises in the operating sphere referred to as stevedoring company are forced to function results in the fact that it is necessary to choose development strategies which are suitable for their commercial activity. For years the operations of port enterprises worldwide have been determined by strong consolidation trends both in the sectorial and inter-sectorial arrangement (Midoro, Musso, Parola, 
2005, pp. 89-106; Parola, Musso, 2007, pp. 259-278; Soppé, Parola, Frémont, 2009, pp. 10-20). In the case of enterprises conducting their commercial activities in the Polish seaports global changes were accompanied by the ones related to the transformation of the Polish economy (Pluciński, 2013, pp. 27-48; Adamowicz, 2012, pp. 206-216). In particular, changes which took place in the subjective, objective and directional structure of the Polish foreign trade are of key importance.

Nowadays, in the case of enterprises which provide technical services in the seaports the two opposing development strategies are used, i.e. the strategy towards specialisation (e.g. container and ferry terminals) and the strategy towards diversification (e.g. port entities handling cargoes from various groups and providing services which are complementary to handling and storage).

Bulk Cargo-Port Szczecin, which operates in the Basen Górniczy area of the port of Szczecin (general and bulk cargo area), employed the latter. The company recently underwent a difficult process of transformation resulting from changes in the cargo structure handled in the port of Szczecin. Before the economic transformation in Poland began, coal handling in export relations had been dominant in this area of the port of Szczecin. The beginning of the 90's brought about significant changes both in the directional structure of the cargoes handled (increased importance of importing) and the objective structure (increased diversification of the cargo structure handled). It is also worth stressing that because of its worst access to the sea (compared to all other seaports which are of primary importance to the Polish economy) the port of Szczecin has been systematically decreasing its share in the market of port services provided in the South Baltic (Pluciński, 2017, 259-271). These factors had a significant influence on the operations conducted by the analysed stevedoring company and determined the choice of its development strategy.

The issues with regard to strategic management in enterprises related to stevedoring companies in the Polish seaports are hardly ever taken up in the literature (see Grzelakowski, Matczak, 2006; Pluciński, 2013; Tubielewicz, 2004). Knowledge in this respect focuses mainly on the issues related to the development of seaports regarded as integrated economic bodies (e.g. Neider, 2013; Grzelakowski, Matczak, 2012; Grzelakowski, 2009, pp. 26-28; Christowa, Christowa-Dobrowolska, 2005; pp. 165-179, Szwankowski, 2000). It is, to a lesser extent, related to the circumstances and directions of development of stevedoring companies.

The subject of this research article is identification, analysis and assessment of justifiability as well as the efficiency of employing the strategy towards diversification in the operations performed by the stevedoring companies in the Polish seaports. Therefore, a case study of Bulk Cargo-Port Szczecin, the biggest stevedoring company of the port of Szczecin, was used.

\section{Methodology}

The research used a single case study method (Yin, 2017) widely used in the analysis of problems of descriptive character. This method is useful in particular in research, the subject of which is to find the answer to the question "how" and "why". Following the principles of using this method, the following research questions have been formulated: why and how the analysed stevedoring company implements a strategy towards diversification of operations? Are the actions taken effective?

The subject of the undertaken research is the activities of the stevedoring company focused on the implementation of the diversification strategy. The subject of the research is the biggest stevedoring company in the port of Szczecin - Bulk Cargo-Port Szczecin, which conducts its operations in the bulk and general cargo area 
of the port of Szczecin. The selection of the research subject was dictated by its high share in the total volume of cargo handling in the port of Szczecin and the various scope of activity, both in terms of the structure and directions of the cargoes handled as well as operations performed for cargo. The analysis of these criteria for the examined company is presented in the Table 1.

Table 1. The share of the analysed stevedoring company in total cargo volume handled by the EU 28 seaports, seaports of the southern Baltic Sea and the port of Szczecin (\%)

\begin{tabular}{ccc}
\hline $\begin{array}{c}\text { The share in cargo volume handled } \\
\text { in EU28 seaports }\end{array}$ & $\begin{array}{c}\text { The share in cargo volume handled } \\
\text { in Baltic seaports }\end{array}$ & $\begin{array}{c}\text { The share in cargo volume handled } \\
\text { in the port of Szczecin }\end{array}$ \\
\hline 0.1 & 3 & $50-60$ \\
\hline
\end{tabular}

Source: own work based on Pluciński (2017), p. 264.

The analysed stevedoring company has undergone a functional changes since the commencement of transformation of the Polish economy (the turn of the 1980s and 1990s): from the dominance of coal handled in export and of other bulk cargoes, to development of transhipment of general cargo and the diversification of bulk cargo handling - in terms of subject (different loads) and directional (different directions - export/import/transit).

In addition to the primary transshipment and short-term storage service, additional services related to increasing the added value of handled cargo (including dividing, combining, sorting, unitizing, etc.) play an increasingly important role in port operations of the analysed stevedoring company.

In order to apply the single case study method, a number of data collection and analysis techniques and tools were used, including primarily own observations, direct interviews and reports from the studied stevedoring company.

\section{Research results}

\section{Determinants of the development of port entepprises in the South Baltic}

Enterprises which provide port services operate in the highly competitive environment. Their operations are influenced by competitive entities which run their businesses in a particular port as well as entities of a similar profile, which function in other seaports, providing services to the same supply base. Globally, competitors with port enterprises include road and rail carriers providing shipping services which are alternative to sea transport. Therefore, a development strategy for this type of business entity should be started with identification and analysis of the most important determinants which influence its operations and development.

The most important determinants of the development of analysed stevedoring company include:

1. Established dominance of maritime transport in providing services to the world trade whose volume increased from 2.5 billion tonnes of cargo in 1970 to approximately 10 billion tonnes in the middle of the second decade of the 21 st century. In the quantitative terms, the biggest part in the maritime transport structure is played by liquid bulk cargoes such as crude oil or gas (29\%) as well as dry bulk cargoes including grains, iron ore, coal, bauxite and phosphate $(23 \%)$.

2. The decreasing role of maritime transport in the entirety of the Polish foreign trade (PFT) as a result of changes in the objective, subjective and directional structure of Poland's trade. In the middle of the 
second decade of the 21 st century both maritime export and maritime import share in the entirety of the PFT transport was at an approximate level of $21 \%$. After the period of clear dominance of export at the end of the first decade of the 21 st century import became predominant in the entirety of the Polish maritime trade turnover. Natural resources constitute a dominant cargo group both in Poland's maritime export and import.

3. The development of the world shipping fleet. From the beginning of the 80 's in the 20th century the total deadweight of the world shipping fleet increased 2.5 - fold from 680 million DWT to 1.7 million DWT in 2015. Bulk carriers constitute the biggest group. The analysis of the sea ship construction market indicates that for the most part the newly constructed ships are bigger than their predecessors. The average age of the operational world fleet vessel (based on the number of vessels) is now 20 years, but it is nearly 10 years in terms of its deadweight. A continued increase in the size of ships, which are ready for use, is expected in the years to come.

4. Changes in the IMO and EU regulations aimed at reducing emissions generated by ships. It is also interesting to note that the European Commission's more and more rigorous approach to the issue of whether the development/redevelopment of the port infrastructure is within the range of public interest fulfilment and is not state aid or it is within the range of business activity.

5. Trends on the main cargo markets which are of interest to the analysed stevedoring company, including predictions about the continued increase in coal import with a simultaneous drop in export in the seaports; a gradual drop of metal ores import to Poland and export of steel products, primarily because of the unique EU policy related to the environmental protection; good prospects for handling soya pellets, and a gradual increase in exporting agricultural products by the Polish seaports in the future; a slight increase in reloading services related to the group of 'other bulk' as a result of anticipated growth in two industrial sectors, i.e. chemical products and construction; a gradual increase in handling cellulose as a result of anticipated growth of import from South America, and a drop in paper reloading services.

6. Investment actions included in the most important strategies for the development of the transport system in Poland related to the improvement of properties of the infrastructure which provides access to the port from the sea (deepening the Świnoujście-Szczecin waterway to a depth of $12.5 \mathrm{~m}$ ) as well as from the mainland (completion of the express road S-3, revitalization of the railway C-E59, making the Oder Waterway navigable with class 3 minimally).

7. Trends related to the development of other port's economic functions, which are different to the transport function, observed in providing broader services than primary services of reloading, inter-port transport and short-term storage, including services related to the ever-growing demand for long-term storage and development of distribution and logistic services.

8. The most important provisions included in the strategies formulated at the higher levels of economic structures, including:

- The White Paper of 2011 (European Commission, 2011), which presents the directions of the EU transport policy development,

- The Program for the development of Polish seaports until 2020 (with prospects until 2030) (Ministerstwo Transportu, Budownictwa i Gospodarki Morskiej, 2012), which is a framework for financing port projects in Poland within the existing and farther EU financial perspective, 
- The Development Strategy of Szczecin to 2025 (Urząd Miasta Szczecin, 2011), The Development Strategy of the Szczecin and Świnoujście Ports until 2027 (Zarząd Morskich Portów Szczecin i Świnoujście SA, 2014); the key provisions in these documents are unambiguous in fostering the development of the operating activity in the port of Szczecin.

\section{Description of the analysed stevedoring company}

The analysed stevedoring company runs its business in the port of Szczecin, which is located in the South Baltic, with a status of one of the four seaports of key importance to the economy of Poland. This port, along with the port of Świnoujście, is managed by Szczecin and Świnoujście Seaports Authority SA (both self-government and state-owned company).

The subject of its business activity falls into the area of the so called active services of a seaport (Misztal, 2010, p. 87). Apart from the primary services related to direct and indirect reloading services (carried out in yards and warehouses) in both the sea-land/land-sea and land-land (wagon-barge) relationship, the company, at customers' request, also provides additional services including packing loose bulk cargo into bags or big bags, creating cargo units, mixing cargoes of different properties, retying bundles, sorting coal or other aggregates.

The primary area of business activities carried out by the analysed stevedoring company is the bulk cargo/ general cargo area of the port of Szczecin The company also has its foothold in the north port/industrial area of the port of Szczecin.

Before the system transformation took place, the operating activity in the bulk cargo/general cargo area of the port of Szczecin was performed in the Bulk Cargo Reloading Area of Szczecin-Świnoujście Seaport Authority (SSSA). Functionally, in that period of time its business activity was primarily focused on fulfilling its transport function, including, first of all, handling coal exported by sea. It was in relation to how tasks were set to the particular seaports in Poland at that time.

In the initial period of the Polish economy transformation three enterprises started their business activities on the land belonging to the analysed company. They include Cargo-Port, Coal-Port and Mas-Port. In 1994 they created one entity - stevedoring company Bulk Cargo-Port Szczecin [limited liability company]. This change aimed at creating a stronger economic body which would be less affected by trade fluctuations in the market of port services (Bernacki, Góra, Luks, 1994, pp. 26-122). This integration also allowed to utilize the human factor and tangible assets better. It also improved the position of the scattered entities in relation to financial institutions.

Business operations of the analysed stevedoring company can now be divided into three functional fields resulting from the operating companies which had previously run their businesses in this area (Table 2).

140 cargoes, which require diversified conditions for reloading and storage services, are handled at analysed stevedoring company. Due to wide variability of assortment and a considerable number of cargoes stored ane time in the insufficient storage area, the zones for handling general cargo, "black" bulk cargo (coal and ores) and "white" general cargo (fertilizers and raw materials used for their production) are not divided in a clear way. It has its negative influence on how reloading and storage services are organised.

The analysed stevedoring company provides reloading services at 10 quays (and one loading pier) with a total length of $3.3 \mathrm{~km}$. They include the deepest quays in the port of Szczecin, containing the Katowickie, Chorzowskie, Gliwickie, Bytomskie and Górnośląskie Quays as well as the Pier. 
Table 2. The areas of operation and business activity of Bulk Cargo-Port Szczecin

\begin{tabular}{ll}
\hline Areas of operation & \multicolumn{1}{c}{ Description of business activity } \\
\hline Mas-Port & $\begin{array}{l}\text { The area for handling bulk cargo is in the Katowicke Peninsula. This area has a very versatile function. The storage areas are } \\
\text { in the hinterland of the quays with maximum depths. Bulk cargoes stored in this area include mainly ores, coke and 'other bulk } \\
\text { cargo'. In the north part there are fields for long-term storage. Warehouses designated mainly for storing cellulose, steel products } \\
\text { and agricultural products predominate in the south part. }\end{array}$ \\
Coal-Port & $\begin{array}{l}\text { The area for handling coal is in the hinterland of the Pier and Bytomskie and Wałbrzyskie Quays. The quays are adapted for } \\
\text { handling cargo mostly in export relations. The Wałbrzyskie Quay provides a limited possibility for unloading coal. }\end{array}$ \\
Cargo-Port & $\begin{array}{l}\text { In the area, which was originally designated for handling general cargo (mainly steel products and wood), loose, bagged and big- } \\
\text { bagged cargoes as well as steel products and other general cargoes are stored. The last area used by the analysed stevedoring } \\
\text { company for its operations is in the port/industrial area. Coke and coal are stored in the hinterland of the Huk Quay. }\end{array}$ \\
\hline
\end{tabular}

Source: own work based on Bulk Cargo-Port Szczecin (2016a).

On the land where the company operates there are 23 storage sites covering a total area of 178,000 square metres, including four unpaved sites covering an area of 40,000 square metres, which are used for long-term storage of bulk cargo. Ores and other bulk cargoes, i.e. coke, pitch, plaster and glaze are stored in bunkers. The analysed stevedoring company has 44 bunkers in total, including 9 roofed bunkers, covering a total area of 65,000 square metres. The company has 23 warehouses covering a total area of 38,500 square metres, designated for storing cellulose, steel products, pellets and fertilizers, as well as two warehouses covering a total area of 6,000 square metres, used for storing grains and feeds (Bulk Cargo-Port Szczecin, 2016a).

The suprastructure of the company consists of reloading devices and automated machines. The company has 23 dock cranes with a lifting capacity of 8 up to 45 tonnes. On the quays with a lower number of operations carried out self-propelled cranes are used. Additionally, the equipment includes: 44 forklifts, 10 tractor units for low loader trailers, 17 loaders (Bulk Cargo-Port Szczecin, 2016a). The buyout of the suprastructure leased from SSSA, concluded by the analysed stevedoring company in 2007 , was an important stage in its development and influenced its relationships with the entity which is managing the port of Szczecin.

The analysed stevedoring company cooperates with a group of entities, which established their production facilities and distribution terminals in the general cargo/bulk cargo area of the port of Szczecin, and is their physical reloading operator. The economic relationships between SSSA and the analysed stevedoring company, which result from the Act on Seaports and Harbours, are based on relationships between the leaseholder and the lessor who owns the land as well as the port infrastructure. These relationships are regulated by the Lease Agreement of 15 September 1994 concluded for a non-fixed time. The company operates on 92.7 hectares of land under the lease.

\section{Analysis and assessment of the company's strategy for diversifying its operations}

The stevedoring company under study executes its strategy towards diversification. Examples of diversification actions carried out by the company in comparison with other reloading and storage enterprises in the Polish seaports are presented in Table 3. 
Table 3. The range of business activity diversification in selected reloading and storage enterprises in the Polish seaports

\begin{tabular}{|c|c|c|c|c|c|}
\hline Examples of reloading and storage enterprises & $\begin{array}{l}\text { Bulk Cargo } \\
\text { Port Szczecin }\end{array}$ & $\begin{array}{c}\text { OT } \\
\text { Port Świnoujście }\end{array}$ & $\begin{array}{l}\text { Port Gdański } \\
\text { Eksploatacja }\end{array}$ & Siark-Port & $\begin{array}{l}\text { Bałtycki Terminal } \\
\text { Drobnicowy }\end{array}$ \\
\hline $\begin{array}{l}\text { Development/modernization of the potential for cargoes } \\
\text { traditionally handled by the company }\end{array}$ & $x$ & & $x$ & $\mathrm{x}$ & $\mathrm{x}$ \\
\hline $\begin{array}{l}\text { Providing a possibility for handling cargoes, which were } \\
\text { handled before, but in a new reloading relationship }\end{array}$ & $\mathrm{x}$ & $\mathrm{x}$ & $\mathrm{x}$ & $x$ & \\
\hline $\begin{array}{l}\text { Creating services on offer for new cargoes which were } \\
\text { not handled before }\end{array}$ & $x$ & $x$ & $x$ & $x$ & $x$ \\
\hline $\begin{array}{l}\text { Creating services on offer for other entities located } \\
\text { on the port land (physical reloading and storage services) }\end{array}$ & $\mathrm{x}$ & $\mathrm{x}$ & $\mathrm{x}$ & $\mathrm{x}$ & $x$ \\
\hline $\begin{array}{l}\text { Creating additional services on offer (excluding the main } \\
\text { reloading and storage service) }\end{array}$ & $x$ & & $x$ & & $x$ \\
\hline
\end{tabular}

Source: Pluciński (2013), p. 134.

In the case of the analysed stevedoring company a very wide spectrum of diversification actions may be observed. This diversification may also be noticed both in the structure of cargoes handled and the range of port services provided. In the first case diversification of business is observed in the decreased significance of once the dominant cargo group 'coal'. Its share decreased from $60 \%$ of the entirety of reloading services (only export relations) to $40 \%$. This cargo is now present in various forms as well as types of energy value, both in export, import and transit. On the port land coal is subject to various logistic services which increase its added value.

However, diversification of port services is observed in reloading services at dedicated distribution terminals (Table 4), in running a bonded warehouse and a temporary warehouse for storing and providing logistics and commercial services as well as dispatching and sorting services.

Table 4. Dedicated distribution terminals located on the land leased by the analysed stevedoring company

\begin{tabular}{lcccc}
\hline \multicolumn{1}{c}{ Name } & Cargo & Quay & Relation & $\begin{array}{c}\text { Annual average of reloading } \\
\text { volume in thousands of tonnes }\end{array}$ \\
\hline Coppers & tar & Wałbrzyskie & export & 40 \\
Nynas & bitumen & Parnica & import & 150 \\
Industrial Quimca del Nalon Polonia & tar & Parnica & export & 80 \\
Partek Nordkalk Polska & grinding plant (for calcareous stone) & Bytomskie, Wałbrzyskie & import & 250 \\
Yoman & aggregates & Katowickie & import & 200 \\
Metraco & sulphuric acid & Półwysep Katowicki & export & $200-300$ \\
\hline
\end{tabular}

Source: own work based on Bulk Cargo-Port Szczecin (2016a).

Examples of logistic and commercial services which were developed on the land leased by the analysed stevedoring company:

- packing loose bulk cargo into bags or big bags,

- mixing various kinds of a particular cargo,

- creating cargo units (palletising, loading and unloading containers, also with cargoes which, in the past, were regarded inappropriate for containerization),

- rearrangement of bundles, packages and straps, 
- sorting, e.g. sorting aggregates into different fractions,

- grinding bulk cargo,

- tagging, wrapping goods in foil, mending transport packaging, etc.

The indicated diversification actions are an answer to the ever-changing expectations of customers who use port services.

The development strategy employed by the company improved its competitive position. In the bulk cargo handling segment the analysed stevedoring company is now the biggest reloading enterprise in Szczecin. The company reloads over $50 \%$ of cargo which goes through the port and is also a leader in handling cargoes from the groups 'coal' and 'ores' (shares of nearly 90\%). The company's share is about $50 \%$ in handling cargoes from the group 'other bulk cargo'. Bulk-Cargo Port Szczecin is also a significant entity in handling general conventional cargo with its share at a level of $30 \%$.

Business operations carried out by the analysed company have their strong influence on the immediate environment. 400 people are permanently employed at analysed stevedoring company. According to the company's statistics the next 400 people are employed by the entities cooperating on a regular basis with regard to reloading, transporting, renovations and repair of the equipment. The influence of an entity such as at analysed stevedoring company on the local environment may also be analysed from the perspective of tax transfers which are made into the local budget. For example, in 2013 that was roughly 2 million zlotys on account of taxes.

The directions of the development of analysed stevedoring company in the context of its strategy towards diversification

In the first half of 2016 the document entitled "A strategy towards development of Bulk Cargo-Port Szczecin until 2020 (with an outlook to 2030)" (Bulk Cargo-Port Szczecin, 2016b) was produced. The most important objectives of the development of the Company were defined in the document. They include:

1. Adaptation of the existing resources for the new maximum depth in the port of Szczecin, which results from deepening the Świnoujście-Szczecin waterway to a depth of $12.5 \mathrm{~m}$.

2. Adaptation of the handling and storage services for the complex structure based on the type, direction and subject of trade cargo in maritime trade carried out by Poland and neighboring countries.

3. Extending storage services which are necessary for the dynamically developing distribution and logistics services.

4. Establishing a flexible range of services related to different transport modes in serving seaport hinterland.

Compared to the rest of the most important Polish seaports, access to the port of Szczecin from the sea is the worst. In the past, i.e. approximately 15 to 20 years ago, the port of Szczecin provided a possibility for handling a new, average size world fleet vessel, but now an average vessel, which has been constructed over the last five years, will be able to enter the port of Szczecin after its aquatorium is deepened to a depth of $12.5 \mathrm{~m}$.

The economic transformation, which has been taking place in Poland and other countries in the region since the last decade of the 20th century, has had its influence on:

- the objective structure of cargoes in the maritime trade (decreased export of raw materials which are cheap in terms of their unit price, an increase in the number of articles which are highly processed),

- cementing commercial relationships with other 'old' EU countries and the so called 'shift in trade effect' as a result of it, 
- change in the quantitative and ownership structure of this trade participants (decreased share of big state entities for the sake of small and medium private businesses).

These changes forced and are still forcing specific actions performed by the storage and reloading companies in the port of Szczecin whose target is to attract cargoes.

The changes, which are taking place in the world maritime transport, including seaports (Misztal, 1985, p. 44), are reflected in a much bigger (than it was in the past) demand for a storage space and areas designated for distribution and logistics services. As a result a big pressure for acquiring new areas for port activities is observed. In Szczecin the vacant port land is not evenly distributed among the most important port areas, forcing one to consider enlarging the port's management borders in the general and bulk cargo area.

Before the economic transformation in the Polish seaports began, rail transport had been dominant in providing services to the supply base. Road transport, whose share in providing services to the port of Szczecin's hinterland is growing rapidly, as well as the accomplished and scheduled projects related to making the Oder Waterway navigable, will have a big influence on operations of the analysed company in the future.

The fulfilment of the determined development objectives of analysed stevedoring company is closely correlated with actions scheduled by the entities which are responsible for improving access to the port of Szczecin from the sea and mainland, spatial development of this port as well as its infrastructure development (Table 5).

Table 5. External actions which are coincident with the development objectives of the analysed stevedoring company

\begin{tabular}{|c|c|}
\hline Action & Detailed actions \\
\hline $\begin{array}{l}\text { Improvement of access to the port } \\
\text { from the sea }\end{array}$ & $\begin{array}{l}\text { deepening the waterway to a depth of } 12.5 \mathrm{~m} \text { along the length of } 62.5 \mathrm{~km} \text { as well as widening, building } \\
\text { and modernising hydraulic structures and redeveloping navigational and VTS tagging objects }\end{array}$ \\
\hline $\begin{array}{l}\text { Improvement of access to the port } \\
\text { from the hinterland }\end{array}$ & $\begin{array}{l}\text { - modernisation of the E59 and C-E59 main railway lines, } \\
\text { - making the Oder Waterway navigable, } \\
\text { - continuation of road S3 construction (stopping at the Czech border) }\end{array}$ \\
\hline $\begin{array}{l}\text { Improvement of "last mile" access } \\
\text { to the port }\end{array}$ & $\begin{array}{l}\text { - improvement of rail access to the port of Szczecin; a complex redevelopment of the track system } \\
\text { at the Szczecin Port Centralny station, } \\
\text { - improvement of road access to the port of Szczecin }\end{array}$ \\
\hline Improvement of port infrastructure & $\begin{array}{l}\text { - improvement of access to the port of Szczecin in the Kaszubski Basin area; redevelopment of the main quays } \\
\text { at the Katowicki Peninsula as a result of modernization of the Świnoujście-Szczecin waterway to a depth } \\
\text { of } 12.5 \mathrm{~m} \text {, } \\
\text { - construction of port infrastructure in the Górnośląski Basin in the port of Szczecin; the project involves } \\
\text { construction of the Dolnoślaski Quay as well as filling and paving the Notecki Basin area, } \\
\text { - preparing the Bytomskie Quay to handle ships with a } 11.15 \mathrm{~m} \text { draught }\end{array}$ \\
\hline Port space development & $\begin{array}{l}\text { extending the management borders of the port of Szczecin with the land located on the other side } \\
\text { of Gdańska Street, designated mainly for the development of the distribution and logistic function }\end{array}$ \\
\hline
\end{tabular}

Resources: own work.

Investment tasks to be taken on by the analysed Company result from the development objectives formulated by the analysed stevedoring company. They include investment tasks in two areas, i.e. investment in reloading equipment and investment in storage areas. In Table 6 these tasks are assigned to the primary development objectives of the analysed stevedoring company. 
Table $\boldsymbol{6}$. The most important actions of the analysed stevedoring company aimed at accomplishing the goals of the company's development strategy

\begin{tabular}{|c|c|c|}
\hline Goals & Development of the handling, transport and logistics potential & Development of the storage potential \\
\hline Objective 1. & $\begin{array}{l}\text { Projects related to the increasing the handling rate related to the } \\
\text { new depths at the most important Company's quays, including } \\
\text { the purchase of a Tukan crane with a lifting capacity of } 50 \text { tonnes } \\
\text { for the Katowickie Quay, modernization of the two cranes at the } \\
\text { Chorzowskie Quay, which will increase their lifting capacity from } \\
16 \text { tonnes to } 25 \text { tonnes, the purchase of new grabs, the purchase } \\
\text { of a new loader to be operated in the holds. }\end{array}$ & $\begin{array}{l}\text { Investments which allow to store bigger cargo batches at a time, } \\
\text { including enlargement of the storage area at the Katowickie } \\
\text { Quay and modernization of the bunkers in the hinterland of the } \\
\text { Bytomskie Quay and Katowickie Quay. }\end{array}$ \\
\hline Objective 2. & $\begin{array}{l}\text { Projects which will adjust the reloading and manipulative } \\
\text { suprastructure for the more complex cargo traffic, including: } \\
\text { modernization of the coal terminal in order to restore its full import } \\
\text { possibilities, the purchase of a new bulldozer, the purchase } \\
\text { of new, self-propelled cranes for handling cargoes in from/to } \\
\text { vessel relationships. }\end{array}$ & $\begin{array}{l}\text { Projects related to the establishment of new warehouse spaces, } \\
\text { tidying storage areas ('black' bulk cargoes separated from 'white' } \\
\text { cargoes), conversion of the Wałbrzyskie Quay in order to handle } \\
\text { and store 'white' bulk cargo and general cargo. }\end{array}$ \\
\hline Objective 3. & $\begin{array}{l}\text { Bearing in mind the Objective } 3 \text {, investments related to the } \\
\text { purchase of forklifts for reloading cellulose and other general } \\
\text { cargoes are intended in the field of investments in the handling } \\
\text { and manipulative suprastructure. }\end{array}$ & $\begin{array}{l}\text { Investments in the storable potential related to the development } \\
\text { of distribution and logistics services, including development of two } \\
\text { warehouses for storing cellulose and other unitized cargoes at the } \\
\text { Regalica Quay, adaptation of the warehouse (which was originally } \\
\text { built for handling soya pellets) for storing cellulose, construction } \\
\text { of a lime warehouse, leasing new port areas (after its borders are } \\
\text { enlarged). }\end{array}$ \\
\hline Objective 4. & $\begin{array}{l}\text { Projects which take into account changes in providing transport } \\
\text { services to the port from the hinterland, including construction } \\
\text { of bunkers for loading lorries (increased handling rate in the } \\
\text { vessel/lorry direct relationship) construction of weighing bunkers } \\
\text { for proper feeding into lorries and wagons with no need to weigh } \\
\text { them on the scales, the purchase of a self-propelled crane to be } \\
\text { used on the scales and storage sites, the purchase of devices for } \\
\text { shunting wagons on port sidings. }\end{array}$ & \\
\hline
\end{tabular}

Source: own work based on Bulk Cargo-Port Szczecin (2016b).

The synthetically presented actions to be justifiably taken by the analysed stevedoring company are an answer to the most important challenges this entity is now facing. For years the analysed stevedoring company has been preparing for such conditions, including changes in the Polish maritime trade (Objective 2), increase in the importance of the distribution and logistic function of the ports (Objective 3), or changes in the share of particular land transport sectors in providing services to the supply base (Objective 4), by taking appropriate investment and organisational actions.

The new and definitely the most important determinant of the company's development is deepening the Szczecin-Świnoujście waterway to a depth of $12.5 \mathrm{~m}$ by the Maritime Office in Szczecin. This project should be then continued within the framework of actions carried out by Szczecin and Świnoujście Seaports Authority SA by deepening the immediate access waters to the most important quays as well as their redevelopment. Therefore, obtaining new areas for the development of port operations will also be an important area of actions carried out by Szczecin and Świnoujście Seaports Authority SA.

In order to achieve realistic effects related to the new depth of the port of Szczecin's aquatorium as well as actions carried out by the Maritime Office in Szczecin and Świnoujście Seaports Authority SA investment actions of the analysed stevedoring company will be coordinated chronologically and substantively. By providing services 
to bigger ships in the port of Szczecin the analysed company will be allowed to continue its strategy towards diversification of its business operations more effectively.

\section{Conclusions}

Changes which take place in the environment of stevedoring companies, both positive and negative, force these entities to choose and accomplish a suitable development strategy. The example of the stevedoring company analysed in the article indicates significant benefits derived from the fulfilment of the strategy towards diversification.

Thanks to its strategy for diversifying cargo, directions and functions the stevedoring company has reached its established position in the market of port services in the South Baltic. The company is also the most important entity which provides technical services in the bulk and general cargo area of the port of Szczecin. The strategy employed by the company is part of the existing and scheduled actions aimed at improving access to the port of Szczecin from the mainland as well as investments in the port infrastructure in Szczecin carried out by Szczecin and Świnoujście Seaports Authority SA.

The efficiency of diversification actions taken by the analysed stevedoring company, and, consequently, improvement of its competitiveness, will be significantly influenced by completing the project to deepen the Świnoujście to Szczecin waterway to a depth of $12.5 \mathrm{~m}$ (Maritime Office in Szczecin), deepening the immediate access waters to the most important quays as well as their redevelopment (Szczecin and Świnoujście Seaports Authority SA) and complementary investments in the handling and storage-related suprastructure (Bulk Cargo-Port Szczecin).

\section{References}

Adamowicz, M. (2012). Przyszłość regulacji problematyki portów morskich. Prawo Morskie, XXVIII, 206-216.

Bernacki, D., Góra, J., Luks, K. (1994). Prywatyzacja w polskich portach morskich. Szczecin: Wydawnictwo Naukowe Uniwersytetu Szczecińskiego.

Bulk Cargo-Port Szczecin (2016a). Internal data.

Bulk Cargo-Szczecin (2016b). Strategia rozwoju Bulk Cargo-Port Szczecin do 2020 roku (z perspektywą do 2030. Internal materials. Szczecin.

Christowa, C., Christowa-Dobrowolska, M. (2005). Modelowanie strategii rozwoju portów morskich na przykładzie portów w Szczecinie i Świnoujściu. In: Materiały V Międzynarodowej Konferencji Naukowej "Porty Morskie” (pp. 165-179). Szczecin: Kreos.

European Commission (2011). Roadmap to a Single European Transport Area: Towards a Competitive and Resource Efficient Transport System: White Paper. Publications Office of the European Union. Retrieved from: https://ec.europa.eu/transport/sites/transport/ files/themes/strategies/doc/2011_white_paper/white-paper-illustrated-brochure_en.pdf.

Grzelakowski, A.S., Matczak, M. (2006), Ekonomika i zarządzanie przedsiębiorstwem portowym. Gdynia: Wydawnictwo Akademii Morskiej w Gdyni.

Grzelakowski, A.S., Matczak, M. (2012). Współczesne porty morskie: Funkcjonowanie i rozwój. Gdynia: Wydawnictwo Akademii Morskiej w Gdyni.

Grzelakowski, A.S. (2009). Wizje i strategie rozwoju polskich portów morskich, Pomorski Przegląd Gospodarczy, 2 (41), 26-28; Retrieved from: https://ppg.ibngr.pl/wp-content/uploads/2013/10/PPG-2-200941.pdf.

Midoro, R., Musso, E., Parola, F. (2005). Maritime liner shipping and the stevedoring industry: market structure and competition strategies. Maritime Policy \& Management, 32 (2), pp. 89-106.

Ministerstwo Transportu, Budownictwa i Gospodarki Morskiej (2012). Program rozwoju polskich portów morskich do 2020 (z perspektywą do 2030). Warszawa.

Misztal, K. (1985). Współczesny rozwój portów morskich. Gdańsk: Wydawnictwo Morskie Gdańsk.

Misztal, K. (2010). Organizacja i funkcjonowanie portów morskich. Gdańsk: Wydawnictwo Uniwersytetu Gdańskiego. 
Neider, J. (2013). Rozwój polskich portów morskich. Gdańsk: Wydawnictwo Uniwersytetu Gdańskiego.

Parola, F., Musso, E. (2007). Market structures and competitive strategies: the carrier-stevedore arm-wrestling in northern European ports. Maritime Policy \& Management, 34 (3), 259-278.

Pluciński, M. (2013). Polskie porty morskie w zmieniającym się otoczeniu zewnętrznym. Warszawa: CeDeWu.

Pluciński, M., Pomoc publiczna w realizacji inwestycji infrastrukturalnych w portach morskich. Przykład portu Szczecin, Problemy Transportu i Logistyki, 2017, 1 (37), 259-271.

Soppé, M., Parola, F., Frémont, A. (2009). Emerging inter-industry partnerships between shipping lines and stevedores: from rivalry to cooperation? Journal of Transport Geography, 17 (1), 10-20.

Szwankowski, S.A. (2000). Funkcjonowanie i rozwój portów morskich. Gdańsk: Wydawnictwo Uniwersytetu Gdańskiego.

Tubielewicz, A. (2004). Zarządzanie strategiczne w portach morskich: globalizacja, integracja, prognozowanie, planowanie, strategie. Gdańsk: Wydawnictwo Politechniki Gdańskiej.

Urząd Miasta Szczecin (2011). Strategia rozwoju Szczecina do 2025. Szczecin. Retrieved from: http://www.szczecin.pl/strategia2025/ index.html\#obowiazujaca.

Yin, R.K. (2017). Case study research and applications: Design and methods. Los Angeles: Sage publications.

Zarząd Morskich Portów Szczecin i Świnoujście SA (2014). Strategia rozwoju portów morskich w Szczecinie i Świnoujściu do 2027. Szczecin.

Cite this article aS: Mańkowska, M., Pluciński, M. (2018). A Strategy Towards Diversification of Operations. The Case Study of the Stevedoring Enterprise. European Journal of Service Management, 4 (28/2), 257-268. DOI: 10.18276/ejsm.2018.28/2-32. 